\title{
Aluminum-Associated Hepatobiliary Dysfunction in Rats: Relationships to Dosage and Duration of Exposure ${ }^{1}$
}

\author{
GORDON L. KLEIN, MELVIN B. HEYMAN, THOMAS C. LEE, NANCY L. MILLER, \\ GOPAL MARATHE, WILLIAM K. GOURLEY, AND ALLEN C. ALFREY
}

\begin{abstract}
Departments of Pediatrics and Pathology, University of Texas Medical Branch, Galveston, Texas; Department of Pediatrics, University of California School of Medicine, San Francisco, California; Division of Pathology, City of Hope Medical Center, Duarte, California; and Medical and Research Services VA Medical Center and University of Colorado School of Medicine, Denver, Colorado
\end{abstract}

\begin{abstract}
Aluminum may contaminate parenteral nutrition solutions and accumulate in bone and liver of patients receiving this therapy. Although aluminum exposure is associated with low-turnover osteomalacia, there are few studies of hepatotoxicity. We therefore studied the effects of aluminum given to rats on total serum bile acid concentration and bile flow to determine if aluminum administration could produce abnormalities. Aluminum was given intravenously as follows: $5 \mathrm{mg} / \mathrm{kg}$ daily for 7 or 14 days and $1 \mathrm{mg} / \mathrm{kg}$ for 14 days. Hepatic aluminum was high in treated rats and undetectable in controls. Total serum bile acid concentrations were significantly higher in treated rats than in pair-fed controls with higher concentrations after 14 days than after 7 days. Bile flow was reduced by $33 \%$ in rats given $5 \mathrm{mg} / \mathrm{kg}$ but not in rats given $1 \mathrm{mg} / \mathrm{kg}$. Hepatic aluminum correlated inversely with bile flow but not with serum bile acid concentration. Aluminum exposure in rats is associated with elevated serum bile acid concentration and diminished bile flow and may play a role in the pathogenesis of parenteral nutrition-induced hepatobiliary dysfunction. (Pediatr Res 23:275-278, 1988)
\end{abstract}

\section{Abbreviations}
Al, aluminum
TPN, total parenteral nutrition
$\mathrm{PE}$, polyetheylene

$\mathrm{Al}$ is a known contaminant of both dialysis solutions $(1,2)$ and components of TPN solutions, including casein hydrolysate (3), calcium and phosphate salts $(4,5)$, albumin $(4,6)$, and heparin (4). Elevated Al content in both liver and bone has been documented in patients with chronic renal failure (7) and in those with severe gastrointestinal disease receiving TPN therapy $(3,8,9)$. Al accumulation in both groups of patients has been linked to a low-turnover vitamin D-resistant osteomalacia (9). However, until recently there has been no evidence to suggest that $\mathrm{Al}$ accumulation in the liver is harmful. Preliminary studies in rats have demonstrated a depression of hepatic mixed function

Received June 8, 1987; accepted November 4, 1987.

Correspondence and request for reprints Gordon L. Klein, M.D., Pediatric Gastroenterology Division, University of Texas Medical Branch, Galveston, TX 77550-2776.

${ }^{1}$ Presented in part at the annual meeting of the Society for Pediatric Research, Anaheim, CA, April 1987. Supported in part by funds from the Veterans Administration and the Children's Liver Foundation. oxidase activity with parenteral Al loading (10) whereas total serum bile acid concentrations were elevated in piglets chronically loaded with $\mathrm{Al}$ when compared to pair-fed controls (11). We investigated the effects of chronic intravenous administration of $\mathrm{Al}$ to rats in order to determine whether $\mathrm{Al}$ could produce hepatic or biliary dysfunction.

\section{METHODS}

The use of rats to study Al-associated hepatobiliary dysfunction was based on their prior use in studying TPN-associated liver disease (12-14) as well as the previous demonstrations of Al toxicity to bone in rats $(15,16)$. Male Wistar rats were prepared with chronic indwelling venous cannulas as follows: under pentobarbital anesthesia $(35 \mathrm{mg} / \mathrm{kg}$ intraperitoneally) a medical grade silastic catheter 0.037 inches external diameter attached to PE tubing (PE 50) was inserted through the jugular vein a distance of $2.5 \mathrm{~cm}$ entering the inferior vena cava. The opposite end of the PE 50 tubing was connected to surgical grade Tygon tubing, $3 / 32$ inches external diameter, and tunneled through the skin. The tubing emerged and was anchored between the scapulae. The animals were allowed to recover for $24 \mathrm{~h}$. Patency of the cannula was maintained by daily injection of 0.4 $\mathrm{ml}$ of heparinized saline $(10 \mathrm{U} / \mathrm{ml})$.

Rats, maintained on standard laboratory rat Chow (Purina 5001, Ralston-Purina Co., St. Louis, MO) and water ad libitum and weighing $175 \pm 11 \mathrm{~g}(\mathrm{SD})$ at the start of the study, were divided into three experimental groups. Littermate control animals for each experimental group (weighing $174 \pm 10 \mathrm{~g}$ ), were pair-fed to eliminate changes brought about by altered nutritional status. Experimental animals received daily intravenous injections of Al chloride, providing either $5 \mathrm{mg} / \mathrm{kg} / \mathrm{day}(5 \mathrm{mg} \times 14)$ or $1 \mathrm{mg} / \mathrm{kg} /$ day of elemental $\mathrm{Al}(1 \mathrm{mg} \times 14)$ for 14 days. A third group received $5 \mathrm{mg} / \mathrm{kg} /$ day of elemental Al for 7 days only $(5 \mathrm{mg} \times 7)$. Control animals received daily injections of the vehicle, $0.85 \%$ saline.

After the experimental loading period, animals again received pentobarbital anesthesia and bile duct and bladder cannulas were placed using PE tubing (PE 10 and PE 90, respectively). Bile and urine were collected for $3 \mathrm{~h}$. At the conclusion of this 3 -h period, serum was collected by carotid artery cannulation. After blood withdrawal the rats were killed by cervical dislocation while still under pentobarbital anesthesia.

Serum and biliary bile acid concentrations were determined fluorometrically using the Sterognost 3- $\alpha$ Flu enzymatic method (Nyegaard and Co., Diagnostics Division, Oslo, Norway) (1719). This technique accounts for all bile acids including muricholates that also have 3- $\alpha$ hydroxyl groups (19). Al was analyzed 
in bile, serum, urine, and liver by flameless atomic absorption spectroscopy (20).

Livers from rats receiving $\mathrm{Al} 5 \mathrm{mg} \times 14$ and pair-fed controls were prepared for electron microscopy. Specimens were fixed in a mixture of $2 \%$ paraformaldehyde and $5 \%$ glutaraldehyde in casodylate buffer for $1 \mathrm{~h}$, washed in phosphate buffer, and fixed in $1 \%$ osmium tetroxide. Each specimen was washed in phosphate buffer, dehydrated in graded alcohol, and embedded in Spurr low viscosity embedding medium. Ultra-thin sections were cut on an LKB ultratome III, counterstained with uranyl acetate and lead citrate, and viewed under a Philips EM 301 electron microscope at an acceleration voltage of $80 \mathrm{kv}$ (11). Light microscopy was not performed on livers from animals in this study.

This study was reviewed and approved by the Research Animal Care Committees of the City of Hope and the University of Texàs Medical Branch.

\section{RESULTS}

At the time of death, the combined mean weights of all Alloaded groups were not different from those for all control groups, $211 \pm 18 \mathrm{~g}$ compared to $212 \pm 19 \mathrm{~g}$, respectively. In addition, no differences in weight gain were present among the various subgroups of experimental animals.

Hepatic Al content was elevated significantly in all three experimental groups compared to their respective pair-fed controls (Fig. 1). Hepatic $\mathrm{Al}$ content did not differ in rats given $\mathrm{Al} 5$ $\mathrm{mg} / \mathrm{kg} /$ day for 7 versus 14 days. Mean hepatic Al content in the rats given $\mathrm{Al} 1 \mathrm{mg} \times 14$ was $35-40 \%$ of mean hepatic $\mathrm{Al}$ content of rats receiving either $5 \mathrm{mg} /$ day regimen. Hepatic Al content never exceeded $1 \mathrm{mg} / \mathrm{kg}$ dry weight in any of the controls. Mean serum levels of $\mathrm{Al}$ in rats given $1 \mathrm{mg} \times 14$ were approximately $50 \%$ of those of the group given $5 \mathrm{mg} \times 14$ (Table 1 ).

Total serum bile acid concentrations were substantially higher in rats from all treatment groups than in pair-fed controls (Fig. 2). The elevation of bile acids was more pronounced after 14 days than after 7 days of Al (Fig. 2). Total serum bile acid concentrations, although clearly elevated compared to controls, were not different between rats given $1 \mathrm{mg} \times 14$ or $5 \mathrm{mg} \times 14$ (Fig. 2).

In the groups given $5 \mathrm{mg} / \mathrm{kg}$ bile flow was significantly reduced compared with controls, whereas bile flow was not different in rats given $1 \mathrm{mg} / \mathrm{kg} /$ day compared with controls (Fig. 2). Bile flow in rats given $5 \mathrm{mg} \times 14$ was reduced by $15 \%$ compared with rats given $5 \mathrm{mg} \times 7$ and by approximately $33 \%$ compared with rats given $1 \mathrm{mg} \times 14$ (Fig. 2).

Regression analysis for all three groups combined revealed an inverse correlation between hepatic $\mathrm{Al}$ and bile flow $(r=0.52$, $p<0.025$ ) but no relationship between hepatic Al and total

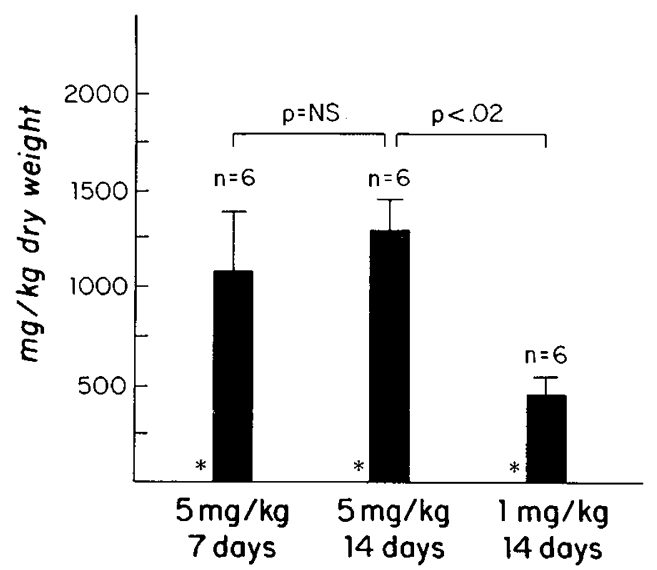

Fig. 1. Hepatic Al content (mean \pm SD) of the three groups of rats receiving $\mathrm{Al} .{ }^{*}$ represents values for hepatic $\mathrm{Al}$ content of the pair-fed controls; all were $<1 \mathrm{mg} / \mathrm{kg}$ dry weight. serum bile acid concentration. It should be noted that hepatic Al was higher in rats given $5 \mathrm{mg} \times 7$ than $1 \mathrm{mg} \times 14$ while serum bile acids were higher in the $1 \mathrm{mg} \times 14$ group. However, the effects of both dose and duration of $\mathrm{Al}$ administration may have interacted in some way to influence these results.

Biliary excretion of bile acids and Al calculated from biliary bile acid concentration, Al concentration, and bile flow are shown in Table 1 along with serum Al levels. Calculated biliary bile acid excretion was not significantly different between $\mathrm{Al}$ and control rats in any of the three groups. Biliary $\mathrm{Al}$ excretion was substantially greater in the experimental animals compared to controls. However, it accounted for only 3-7\% of the quantity of $\mathrm{Al}$ excreted in the urine. Analysis of covariance revealed that within each of the three groups and with all three groups combined, a direct relationship exists between biliary/urinary $\mathrm{Al}$ excretion and hepatic Al content, with $p=0.033$.

Electron microscopic examination of the liver from Al-loaded rats and controls failed to reveal any abnormalities. Specifically, there were no inclusions or membrane changes seen.

\section{DISCUSSION}

Our data show that parenteral administration of $\mathrm{Al}$ to rats can result in the production of elevated total serum bile acid concentrations alone or in combination with decreased bile flow. These effects are both dose dependent and time dependent. Moreover, they occurred despite continued enteral stimulation provided by the pair-feeding design.

The mechanism for these cholestatic effects associated with $\mathrm{Al}$ loading remains unclear. The present data fail to demonstrate abnormalities in hepatic ultrastructure or a measurable decrease in biliary bile acid excretion, which is a phenomenon observed with infusions of TPN solutions into rats (14). The inverse relationship between hepatic $\mathrm{Al}$ content and bile flow would suggest that accumulation of $\mathrm{Al}$ in the liver may in some way impede bile flow. However, unchanged bile flow and biliary bile acid excretion in rats given $\mathrm{Al} 1 \mathrm{mg} / \mathrm{kg} /$ day compared to controls, despite the elevations of serum bile acid concentrations, may be due in part to the low circulating bile acid concentrations ( $\mu \mathrm{mol} /$ liter) compared to the relatively high levels of biliary bile acid (mmol/liter). For example, very small decrements in hepatic bile acid clearance are reflected in large changes in total serum bile acid levels. Herein we did not determine biochemical measurements of hepatocyte injury such as serum transaminase levels. Thus, despite lack of histologic evidence of hepatocyte injury by Al we cannot exclude the possibility that Al may damage hepatocyte plasma membranes, interfering with bile acid uptake. Also the reduction in bile flow without a decrease in biliary bile acid excretion suggests an effect of $\mathrm{Al}$ on bile acid independent bile flow. However, additional studies would be required to support or refute this speculation (21).

$\mathrm{Al}$ is known to have other effects on the liver including reduction of mixed function oxidase activity in rats, a phenomenon also reported in rats receiving TPN solutions (23) and in cholestatic patients (23). However, the mechanism by which $\mathrm{Al}$ raises serum bile acids or impairs bile flow is unknown.

Another metal, manganese, has been shown to cause cholestasis in rats when given in combination with bilirubin (24-26). Study of this phenomenon has demonstrated that there are ultrastructural changes, including a loss of bile canalicular membrane microvilli and pericanalicular vacuolization occurring with a $20 \%$ decrease in bile flow; when bile flow returned to normal the histologic changes resolved $(24,25)$. No data are available regarding the effects of giving bilirubin to Al-loaded rats. Furthermore no ultrastructural changes have been associated with a $33 \%$ decrease in bile flow seen with Al-loaded rats. In addition, manganese is excreted through the bile while there is very little biliary excretion of Al. Moreover, the liver may handle a trivalent cation such as $\mathrm{Al}$ differently from a divalent cation such as 
Table 1. Biliary excretion of bile acids and Al [mean $\pm S D$ (range)]

\begin{tabular}{|c|c|c|c|c|c|c|}
\hline \multirow[b]{2}{*}{ Group } & \multirow[b]{2}{*}{$n$} & \multicolumn{2}{|c|}{ Biliary bile acid } & \multirow{2}{*}{$\begin{array}{c}\text { Biliary Al } \\
\text { excretion } \\
(\mu \mathrm{g} / \mathrm{h} / \mathrm{g} \text { liver })\end{array}$} & \multirow{2}{*}{$\begin{array}{c}\text { Biliary/urine } \mathrm{Al} \\
\text { excretion } \\
(\mu \mathrm{g} / \mathrm{h} / \mu \mathrm{g} / \mathrm{h} \times 100)\end{array}$} & \multirow[b]{2}{*}{$\begin{array}{l}\text { Serum Al } \\
(\mu \mathrm{g} / \text { liter })\end{array}$} \\
\hline & & $\begin{array}{c}\text { Concentration } \\
(\mu \mathrm{mol} / \text { liter })\end{array}$ & $\begin{array}{c}\text { Excretion } \\
(\mu \mathrm{mol} / \mathrm{h} / \mathrm{g} \text { liver })\end{array}$ & & & \\
\hline $5 \mathrm{mg} / \mathrm{kg} /$ day & & $20.8 \pm 4.5$ & $1.77 \pm 0.83$ & $0.06 \pm 0.04^{*}$ & $3 \pm 2$ & $653 \dagger \pm 296$ \\
\hline $\begin{array}{l}\times 14 \text { days } \\
\text { Control }\end{array}$ & 7 & $\begin{array}{l}(12.7-26.5) \\
25.4 \pm 7.4 \\
(15.8-32.9)\end{array}$ & $\begin{array}{l}(0.98-3.38) \\
3.07 \pm 1.29 \\
(2.21-5.82)\end{array}$ & $\begin{array}{c}(0.02-0.13) \\
0.002 \pm 0.001 \\
(0.001-0.004)\end{array}$ & $\begin{array}{c}(1.2-5.7) \\
\ddagger\end{array}$ & $\begin{array}{c}(312-842) \\
<10\end{array}$ \\
\hline $\begin{array}{l}5 \mathrm{mg} / \mathrm{kg} / \mathrm{day} \\
\times 7 \text { days } \\
\text { Control }\end{array}$ & 8 & $\begin{array}{l}22.9 \pm 3.9 \\
(16.0-26.9) \\
20.0 \pm 5.9 \\
(14.3-31.3)\end{array}$ & $\begin{array}{l}2.29 \pm 0.35 \\
(1.65-2.74) \\
2.34 \pm 0.63 \\
(1.52-3.45)\end{array}$ & $\begin{array}{c}0.07 \pm 0.07 \dagger \\
(0.03-0.25) \\
0.001 \pm 0.0004 \\
(0.0005-0.0013)\end{array}$ & $\begin{array}{c}4 \pm 5 \\
(0.2-13) \\
\ddagger\end{array}$ & NDß \\
\hline $\begin{array}{l}1 \mathrm{mg} / \mathrm{kg} / \text { day } \\
\times 14 \text { days } \\
\text { Control }\end{array}$ & 6 & $\begin{array}{l}20.8 \pm 1.6 \\
(19.0-23.1) \\
19.2 \pm 3.1 \\
(15.1-23.2)\end{array}$ & $\begin{array}{l}2.64 \pm 0.74 \\
(1: 19-3.19) \\
2.33 \pm 0.41 \\
(1.84-3.01)\end{array}$ & $\begin{array}{c}0.04 \pm 0.02 * \\
(0.02-0.07) \\
0.001 \pm 0.0001 \\
(0.0005-0.0007)\end{array}$ & $\begin{array}{c}7 \pm 3 \\
(2.1-11.6) \\
\ddagger\end{array}$ & $\begin{array}{c}341 \pm 37 \\
(198-582) \\
<10\end{array}$ \\
\hline
\end{tabular}

$* p<0.02$ versus controls by sign test. ND $=$ not determined; $++\mathrm{n}=3$ only

$\dagger n=3$ only.

$\ddagger$ Ratio not given for controls due to the very small quantities of Al measured in controls.

$\S$ Not determined.

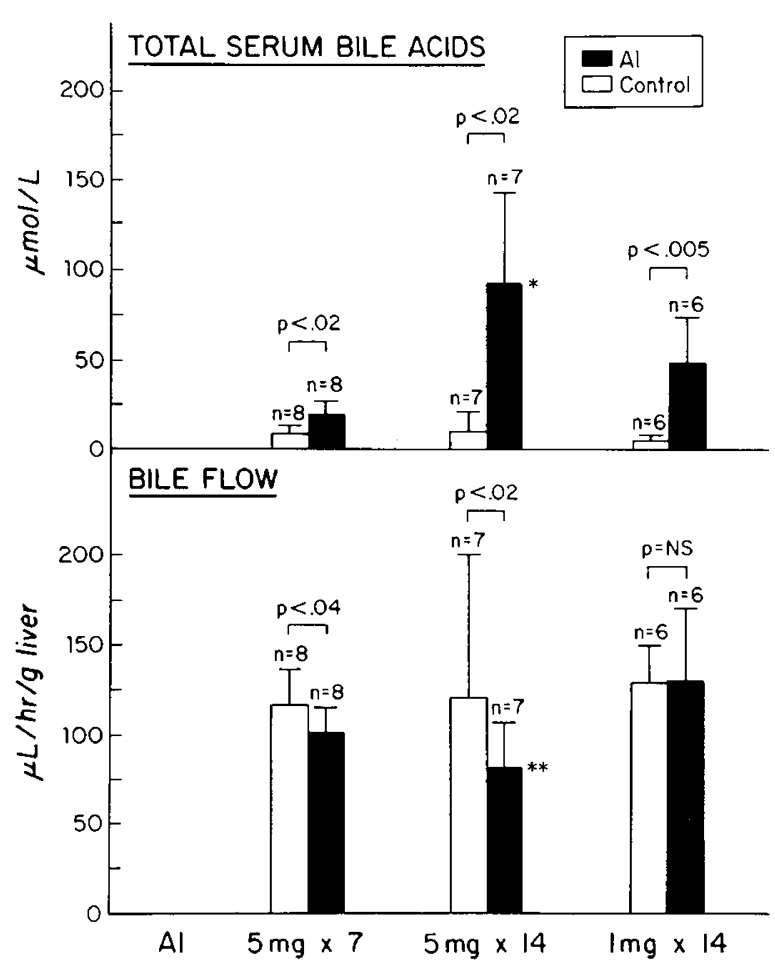

Fig. 2. The effect of duration and dose of $\mathrm{Al}$ on total serum bile acid concentration and bile flow. Values depicted represent mean \pm SD. Five $\mathrm{mg} \times 7$ represents rats receiving $5 \mathrm{mg}$ elemental $\mathrm{Al} / \mathrm{kg} /$ day for 7 days; 5 $\mathrm{mg} \times 14$ represents rats receiving the same amount of $\mathrm{Al}$ for 14 days; 1 $\mathrm{mg} \times 14$ represents rats receiving $1 \mathrm{mg}$ elemental $\mathrm{Al} / \mathrm{kg} /$ day for 14 days. * represents a significant elevation of serum bile acids $(p<0.05)$ in the $5 \mathrm{mg} \times 14$ versus the $5 \mathrm{mg} \times 7$ group. ${ }^{* *}$ represents a significant depression of bile flow $(p<0.05)$ in the $5 \mathrm{mg} \times 14$ versus the $5 \mathrm{mg} \times 7$ group and the $1 \mathrm{mg} \times 14$ group.

manganese. These differences make it difficult to postulate a similar mode of action of these two metals on the liver.

Our data indicating that biliary excretion of $\mathrm{Al}$ accounts for a small proportion of overall $\mathrm{Al}$ excretion during chronic $\mathrm{Al}$ administration is similar to data obtained by Kovalchik et al. (27) in dogs given a single large bolus of $\mathrm{Al}$ and to enterostomal $\mathrm{Al}$ excretion in TPN patients who were chronically loaded with $\mathrm{Al}$ (28). The present data are the first to our knowledge to be obtained by direct bile duct cannulation in animals given large doses of $\mathrm{Al}$ for an extended period of time.

Although it appears that biliary Al excretion may be of little importance after parenteral administration, biliary Al concentration was recently reported to exceed urinary $\mathrm{Al}$ concentration in candidates for liver transplantation with normal renal function who ingested Al-containing antacids (29). Even though excretion rates of $\mathrm{Al}$ via both routes were not compared, this observation raises the possibility that $\mathrm{Al}$ absorbed after oral intake may be handled differently by the liver than $\mathrm{Al}$ administered intravenously.

The Al content of today's noncasein-containing TPN solutions currently given to infants can range from 30 to $300 \mu \mathrm{g} /$ liter (30). At the upper range this could represent a load of $30 \mu \mathrm{g} / \mathrm{kg} / \mathrm{day}$ given to premature infants often for several months. Although the daily load of $\mathrm{Al}$ is clearly less than in the rats we report, the duration of the TPN treatment could result in a significant amount of $\mathrm{Al}$ accumulation. Thus, the hepatic $\mathrm{Al}$ content of the rats given $1 \mathrm{mg} / \mathrm{kg} /$ day for 14 days is similar to that observed in Al-intoxicated chronic dialysis patients (31) and approximately 2 -fold greater than the quantities determined in infants receiving chronic TPN (8). Thus, although it is not reasonable to extrapolate from rats to humans, chronic $\mathrm{Al}$ loading may be an additional factor contributing to TPN-associated liver disease. A prospective study of premature infants receiving parenteral nutrition in which the Al concentration of TPN solution, serum, and urine can be related to liver function would provide indications of whether Al may be an additional factor in the pathogenesis of TPN-associated hepatobiliary dysfunction.

Acknowledgments. The authors are grateful to Rebecca Van Dyke, M.D. of the University of California, San Francisco for her review of the manuscript and constructive suggestions and to L. Robert Hill, M.S., City of Hope Medical Center for statistical analysis. Valuable technical assistance was rendered by Hsein-Chen Tseng and valuable secretarial assistance was provided by Wilma Nance.

\section{REFERENCES}

1. Platts MM, Goode GC, Hislop JS 1977 Composition of the domestic water supply and the incidence of fractures and encephalopathy in patients on 
home dialysis. Br Med J 2:657-660

2. Parkinson IS, Ward MK, Feest TG, Fawcett RWP, Kerr DNS 1979 Fracturing dialysis osteodystrophy and dialysis encephalopathy: an epidemiological survey. Lancet 1:406-409

3. Klein GL, Alfrey AC, Miller NL, Sherrard DJ, Hazlet TK, Ament ME, Coburn JW 1982 Aluminum loading during total parenteral nutrition. Am J Clin Nutr 35:1425-1429

4. Sedman AB, Klein GL, Merritt RJ, Miller NL, Weber KO, Gill WL, Anand $\mathrm{H}$, Alfrey AC 1985 Evidence of aluminum loading in infants receiving intravenous therapy. N Engl J Med 312:1337-1343

5. deVernejoul MC, Messing B, Modrowski D, Bielakoff J, Buisine A, Miravet L 1985 Multifactorial low remodeling bone disease during cyclic total parenteral nutrition. J Clin Endocrinol Metab 60:109-113

6. Milliner DS, Shinaberger JH, Shuman P, Coburn JW 1985 Inadvertent aluminum administration during plasma exchange due to aluminum contamination of albumin replacement solutions. N Engl J Med 312:165-167

7. Alfrey AC 1983 Aluminum. Adv Clin Chem 23:69-91

8. Klein GL, Berquist WE, Ament ME, Coburn JW, Miller NL, Alfrey AC 1984 Hepatic aluminum accumulation in children on total parenteral nutrition. $J$ Pediatr Gastroenterol Nutr 3:740-743

9. Ott SM, Maloney NA, Klein GL, Alfrey AC, Ament ME, Coburn JW, Sherrard DJ 1983 Aluminum is associated with low bone formation in patients receiving chronic parenteral nutrition. Ann Intern Med 98:910-914

10. Bidlack WR, Brown RC, Meskin MS, Lee TC, Klein GL 1987 Effect of aluminum on the hepatic mixed function oxidase and drug metabolism. Drug-Nutr Interact 5:33-42

11. Klein GL, Sedman AB, Heyman MB, Marathe G, Battifora HA, Worrall JL, Horst RL, Brewer GJ, Miller NL, Alfrey AC 1987 Hepatic abnormalities associated with aluminum loading in piglets. JPEN 11:293-297

12. Merritt RJ, Sinatra FR, Henton D, Neustein H 1984 Cholestatic effect of intraperitoneal administration of tryptophan in suckling rat pups. Pediatr Res 18:904-907

13. Gimmon Z, Kelley RE, Simko V 1982 Total parenteral nutrition solution increases bile lithogenicity in the rat. J Surg Res 32:256-263

14. Heyman MB, Ling V, Thaler MM 1984 Effects of total parenteral nutrition (TPN) on biliary function in rapidly growing rats. Pediatr Res 18:119A(abstr)

15. Ellis HA, McCarthy JH, Herrington J 1979 Bone aluminum in haemodialyzed patients and in rats injected with aluminum chloride: relationship to impaired bone mineralization. J Clin Pathol 32:832-844

16. Goodman WG, Gilligan J, Horst R 1984 Short-term aluminum administration in the rat: effects on bone formation. $\mathrm{J}$ Clin Invest 73:171-181

17. Mashiga $F$, Imai K, Osuga $T 1976 \mathrm{~A}$ simple and sensitive assay of total serum bile acids. Clin Chim Acta 70:79-86

18. Osuga T, Mitamura K, Mashiga F, Imai K 1977 Evaluation of fluorometrically estimated serum bile acids in liver disease. Clin Chim Acta 75:81-90

19. Hsia SL 1971 Hyocholic and muricholic acids. In: Nair PP, Kritchevsky D (eds) The Bile Acids: Chemistry, Physiology and Metabolism. Vol I, Chemistry. Plenum, New York, pp 102-106

20. LeGendre GR, Alfrey AC 1978 Measuring picogram amounts of aluminum in biological tissue by flameless atomic absorption analysis of a chelate. Clin Chem 22:53-56

21. Baker AL, Wood RAB, Moossa AR, Boyer JL 1979 Sodium taurocholate modifies the bile acid independent fraction of canalicular bile flow in the rhesus monkey. J Clin Invest 64:312-320

22. Knodell RG, Steele NM, Dannar G, Guengerich FP 1987 Alterations in turnover and isozyme patterns of cytochrome P-450 in rats receiving total parenteral nutrition. Clin Res 35:409A(abstr)

23. Kawata S, Imai $Y$, Inada $M$, Tamura $S$, Miyoshi S, Nishikawa $M$, Minami $Y$, Tarui S 1987 Selective reduction of hepatic cytochrome P 450 content in patients with intrahepatic cholestasis. A mechanism for impairment of microsomal drug oxidation. Gastroenterology 92:299-303

24. Ayotte P, Plaa GL 1985 Hepatic subcellular distribution of manganese in manganese and manganese-bilirubin induced cholestasis. Biochem Pharmacol 34:3857-3865

25. DeLamirande E, Tuchweber B, Plaa GL 1982 Morphological aspects of manganese-bilirubin induced cholestasis. Liver 2:22-27

26. Witzleben CL, Boyer JL, Ng O 1987 Manganese-bilirubin cholestasis: further studies in pathogenesis. Lab Invest 56:151-154

27. Kovalchik MT, Kaehny WD, Jackson T, Alfrey AC 1978 Aluminum kinetics during hemodialysis. J Lab Clin Med 92:712-716

28. Klein GL, Ott SM, Alfrey AC, Sherrard DJ, Hazlet TK, Miller NL, Maloney NA, Berquist WE, Ament ME, Coburn JW 1982 Aluminum as a factor in the bone disease of long-term parenteral nutrition. Trans Assoc Am Phys 95:155-164

29. Williams JW, Vera SR, Peters TG, Luther RW, Bhattacharya S, Spears H, Graham A, Pitcock JA, Crawford AJ 1986 Biliary excretion of aluminum in aluminum osteodystrophy with liver disease. Ann Intern Med 104:782-785

30. Klein GL, Unusual sources of aluminum. In: DeBroe ME, Coburn JW (eds) Aluminum and Renal Failure. Martinus Nijhoff, Dorsdrecht, (in press)

31. Alfrey AC 1980 Aluminum metabolism in uremia. Neurotoxicology 1:43-53 